\title{
QUANTITATIVE RELATIONS BETWEEN THE IMPLEMENTATION OF INDUSTRY MANAGEMENT SYSTEMS IN EUROPEAN UNION COUNTRIES
}

\author{
Radosław WOLNIAK \\ Silesian University of Technology, Faculty of Organization and Management, Zabrze; rwolniak@polsl.pl, \\ ORCID: 0000-0003-0317-9811
}

Purpose: The purpose of this publication is to investigate the linear correlation relationship between the deployment of five certified management systems (ISO 9001:2015; ISO 14001:2015; ISO 27001:2013 and ISO 45001:2018) in organizations operating within the European Union.

Design/methodology/approach: Critical literature analysis. Analysis of secondary sources data about number of certifications (ISO 9001; ISO 14001, ISO 45001, ISO 22000, ISO 27001) in EU countries in 2018.

Findings: The publication focuses on the analysis of quantitative relations between the industry standards that make up the integrated management system. The focus was on the three most common systems: quality management system (ISO 9001:2015), environmental management system (ISO 14001:2015) and occupational health and safety management system (ISO 45001:2018). In addition, the analysis took into account two systems often occurring as a component of integrated systems: ISO 27001:2013 information security management system and ISO 22000:2018 food safety management system, which are industry standards that make up the integrated management system.

Originality/value: Detailed analysis of relations between numbers of main ISO certificates in EU countries.

Keywords: quality management, environmental management, occupational health and safety management, management system, ISO 9001, ISO 14001, ISO 45001, ISO 22000, ISO 27001.

Category of the paper: research paper.

\section{Introduction}

Nowadays, integrated management systems are more and more often implemented in enterprises. These systems consist of various certified management systems implemented in the form of an integrated system, usually based on a quality management system. The integrated 
management system can be based on any existing certified management system based on the concept of ISO management system (Senczyk, 2014).

The convergence of many elements of quality, environmental and occupational health and safety management systems and other systems based on ISO requirements causes that, among various types of organizations, there is a growing conviction about the need to integrate them into one general management system (Grudowski, 2001). This type of approach is now standard in many organizations and only in a few there are several systems functioning separately (Zymonik et al., 2013). The basic task of this kind of integration can be to streamline and optimize the processes implemented within the organization and to ensure cooperation of individual management systems, taking into account external processes implemented by suppliers and subcontractors (Ejdys et al., 2012).

The purpose of this publication is to investigate the linear correlation relationship between the deployment of five certified management systems (ISO 9001:2015; ISO 14001:2015; ISO 27001:2013, and ISO 45001:2018) in organizations operating within the European Union.

Organization's management system is an ordered set of management tools, procedures and rules, as well as the organization's management apparatus, which is related to the external environment (Krzyżanowski, 1992). The quality management system based on the ISO 9001 standard concerns the management of the organization and its activities (Urbaniak, 2006; Krawczuk, 2016; Wolniak, 2017; Wolniak, and Sułkowski, 2015; Pacana, and Stadnicka, 2017). Such system can function in any organization, regardless of its profile, if its aim is to meet the customers needs (Krawczuk, 2016; Malindžák et al., 2017; Gębczyńska, and Wolniak, 2018; Wolniak, 2011, 2013, 2017, 2018; Sułkowski and Wolniak, 2018; Wolniak, and Skotnicka-Zasadzień, 2014).

The environmental management system, based on the requirements of the ISO 14001:2015 standard, is a part of the organization's management system, which is used to implement the environmental policy and manage its various environmental aspects (Olkiewicz, and Wolniak, 2018; Pacana, et al., 2017; Psomas et al., 2011, Qi et al., 2013; Searcy et al., 2012). This system identifies potential environmental hazards related to the activities of the organization. It helps to identify prevention possibilities and how to respond to such threats (Pacana, and Ulewicz, 2017).

The occupational health and safety management system, based on the requirements of ISO 45001, is based on the directives of the International Labor Organization. Implementation of this standard allows deployment of systemic solutions in occupational health and safety, which cause an increase in the efficiency of occupational health and safety management system in such aspects as: adaptation of the occupational health and safety management system to the changing environment, identification of both risks and opportunities, compliance with legal requirements and development of leadership and participation of employees in management (Ewertowski, 2018; Górny, 2017). 
ISO 27001 system is an international standard for information security management systems. Implementation of the ISO 27001 standard in an organization allows for maintaining confidentiality, integrity and availability of information that is of measurable value to the organization, or whose protection results from relevant legal regulations. ISO 27001 standard contains requirements for Information Security System. It defines the requirements necessary to establish, implement, manage, monitor and review the organization's documented information security management system (Wolska, 2012; Bielawa, 2008; Senkus, and Domańska-Szaruga, 2011; Maleszka, 2011).

ISO 22000 standard - Food safety management systems. The requirements for each organization in the food chain focus on the traceability and safety of the production of raw materials and finished food products. The international standard specifies the requirements for the food safety management system for organizations in the food chain that must demonstrate their ability to control food safety risks to ensure that food is safe during consumption (Wysokińska-Senkus, 2010; Turlejska, 2010).

\section{Methodology}

The presented publication deals with the issue of relations between selected industry standards that make up an integrated management system. The focus was on the three most common systems: quality management system (ISO 9001:2015), environmental management system (ISO 14001:2015) and occupational health and safety management system (ISO 45001:2018). In addition, the analysis took into account two systems often occurring as components of integrated systems: ISO 27001:2013 information security management system and ISO 22000:2018 food safety management system.

The analysis included countries belonging to the European Union, in which all analyzed certificates are present (thus, Malta, Luxembourg and Slovenia were not included). Number of individual certificates for the countries analyzed in the publication was assumed according to ISO Survey 2018 (ISO Survey, 2018). Relevant data is presented in Table 1.

Since the integrated management systems are almost always based on a quality management system, the following hypothesis can be formulated:

H1: the presence of other industry management systems is positively correlated with the presence of ISO 9001:2015 quality management system in organizations. 
Table 1.

ISO 9001:2015; ISO 14001:2015; ISO 27001:2013; ISO 22000:2018 and ISO 45001:2018 certificates in European Union countries

\begin{tabular}{|c|l|c|c|c|c|c|}
\hline No. & \multicolumn{1}{|c|}{ Country } & $\begin{array}{c}\text { ISO } \\
\mathbf{9 0 0 1 : 2 0 1 5}\end{array}$ & $\begin{array}{c}\text { ISO } \\
\mathbf{1 4 0 0 1 : 2 0 1 5}\end{array}$ & $\begin{array}{c}\text { ISO } \\
\mathbf{2 7 0 0 1 : 2 0 1 3}\end{array}$ & $\begin{array}{c}\text { ISO } \\
\mathbf{2 2 0 0 0 : 2 0 1 8}\end{array}$ & $\begin{array}{c}\text { ISO001:2018 } \\
\mathbf{4 5 0 0}\end{array}$ \\
\hline 1 & Austria & 4896 & 1079 & 391 & 82 & 175 \\
\hline 2 & Belgium & 4783 & 1012 & 208 & 161 & 50 \\
\hline 3 & Bulgaria & 6534 & 1946 & 404 & 361 & 78 \\
\hline 4 & Czech Republic & 12638 & 4266 & 711 & 165 & 26 \\
\hline 5 & Croatia & 2547 & 1024 & 158 & 71 & 5 \\
\hline 6 & Cyprus & 935 & 216 & 43 & 235 & 15 \\
\hline 7 & Denmark & 4975 & 1012 & 116 & 227 & 56 \\
\hline 8 & Estonia & 1639 & 520 & 19 & 23 & 314 \\
\hline 9 & Finland & 7739 & 1467 & 121 & 108 & 77 \\
\hline 10 & France & 58467 & 6084 & 925 & 154 & 208 \\
\hline 11 & Germany & 73559 & 8028 & 2003 & 479 & 483 \\
\hline 12 & Greece & 6773 & 1415 & 852 & 1996 & 15 \\
\hline 13 & Hungary & 9099 & 2391 & 735 & 258 & 24 \\
\hline 14 & Ireland & 2854 & 957 & 311 & 70 & 170 \\
\hline 15 & Italy & 125994 & 15118 & 1818 & 1376 & 1446 \\
\hline 16 & Netherlands & 13623 & 2181 & 1606 & 510 & 181 \\
\hline 17 & Latvia & 1113 & 336 & 44 & 63 & 4 \\
\hline 18 & Lithuania & 1967 & 914 & 149 & 60 & 57 \\
\hline 19 & Poland & 14964 & 2921 & 1503 & 815 & 99 \\
\hline 20 & Portugal & 8804 & 1382 & 160 & 452 & 201 \\
\hline 21 & Romania & 10916 & 4553 & 821 & 906 & 40 \\
\hline 22 & Slovakia & 3656 & 1687 & 150 & 88 & 69 \\
\hline 23 & Spain & 59425 & 12198 & 1950 & 793 & 670 \\
\hline 24 & Sweden & 36950 & 11201 & 4723 & 146 & 1525 \\
\hline 25 & United Kingdom & 3598 & 266 & 62 & 410 \\
\hline
\end{tabular}

Source: own work on basis of data from: (ISO Survey, 2018).

\section{Results and discussion}

Using data on the number of individual certified management systems in the studied countries of the European Union, Table 2 summarizes the linear correlations between individual certificates. The table shows that there are high correlation coefficients between numerous systems of statistical significance of $\alpha=0.05$ (Table 2 shows statistically significant correlations in bold). ISO 9001:2015 quality management system and ISO 14001:2015 environmental management system are the most correlated - in this case the correlation coefficient is 0.903 . Strong correlation of 0.963 is also present in the case of ISO 1400:2015 environmental management system and ISO 45001:2018 occupational health and safety management system. The third place is occupied by ISO 27001:2013 information security management system, which is correlated with occupational health and safety management system at the level of 0.791 and with environmental management system at the level of 0.764 . 
As far as the quality management system based on ISO 9001:2015 requirements is concerned, it is correlated on a statistical significance level of $\alpha=0.05$ with all other studied systems. This confirms the earlier H1 hypothesis and the claims present in the literature, that the quality management system is usually the basis for the implementation of all integrated systems. Very rarely there are organizations that implement other certified management systems without a quality management system.

\section{Table 2.}

Correlation between number of ISO 9001:2015; ISO 14001:2015; ISO 27001:2013; ISO 22000:2018 and ISO 45001:2018 certificates in European Union countries ${ }^{1}$

\begin{tabular}{|l|c|c|c|c|c|}
\hline & $\begin{array}{c}\text { ISO } \\
\text { 9001:2015 }\end{array}$ & $\begin{array}{c}\text { ISO } \\
14001: 2015\end{array}$ & $\begin{array}{c}\text { ISO } \\
\mathbf{2 7 0 0 1 : 2 0 1 3}\end{array}$ & $\begin{array}{c}\text { ISO } \\
\mathbf{2 2 0 0 0 : 2 0 1 8}\end{array}$ & $\begin{array}{c}\text { ISO } \\
\mathbf{4 5 0 0 1 : 2 0 1 8}\end{array}$ \\
\hline ISO 9001:2015 & - & $\mathbf{0 . 9 0 3}$ & $\mathbf{0 . 5 6 1}$ & $\mathbf{0 . 4 1 5}$ & $\mathbf{0 . 7 4 6}$ \\
\hline ISO 14001:2015 & $\mathbf{0 . 9 0 3}$ & - & $\mathbf{0 . 7 6 4}$ & 0.381 & $\mathbf{0 . 8 6 3}$ \\
\hline ISO 27001:2013 & $\mathbf{0 . 5 6 1}$ & $\mathbf{0 . 7 6 4}$ & - & 0.274 & $\mathbf{0 . 7 9 1}$ \\
\hline ISO 22000:2018 & $\mathbf{0 . 4 1 5}$ & 0.381 & 0.274 & - & 0.218 \\
\hline ISO 45001:2018 & $\mathbf{0 . 7 4 6}$ & $\mathbf{0 . 8 6 3}$ & $\mathbf{0 . 7 9 1}$ & 0.218 & - \\
\hline
\end{tabular}

Source: author's own work.

Figure 1 shows the relationship between the number of ISO 9001:2015 certificates and the number of ISO 14001:2018 certificates for the studied European Union countries. The figures in specific points denote individual countries in accordance with the ordinal number in Table 1. Based on the figure, one can say that for most of the countries there is a direct relation between the number of ISO 9001 certificates and the number of ISO 14001 certificates.

The number of ISO 14001 certificates in a given country can be defined as the following linear function of the number of ISO 9001 certificates.

Number of environmental management system certificates $=1,141.92+0.122 *$ Number of quality management system certificates.

Most of the studied countries, except four of them, are in the confidence interval of 0.95 . In two countries (Spain and the United Kingdom) there is an over-representation of implemented environmental management systems in comparison with quality management systems. In two countries (France and Germany) there is a slight over-representation of quality management systems, in comparison with the number of implemented environmental management systems. An interesting case is Italy, where there is the highest number of certified quality and environmental management systems in the European Union. Causes of this phenomenon are widely discussed by the author of this publication in: Horodecka, and Wolniak, 2015 .

\footnotetext{
${ }^{1}$ The table shows statistically significant correlations at the level of $\alpha=0.05$ in bold.
} 


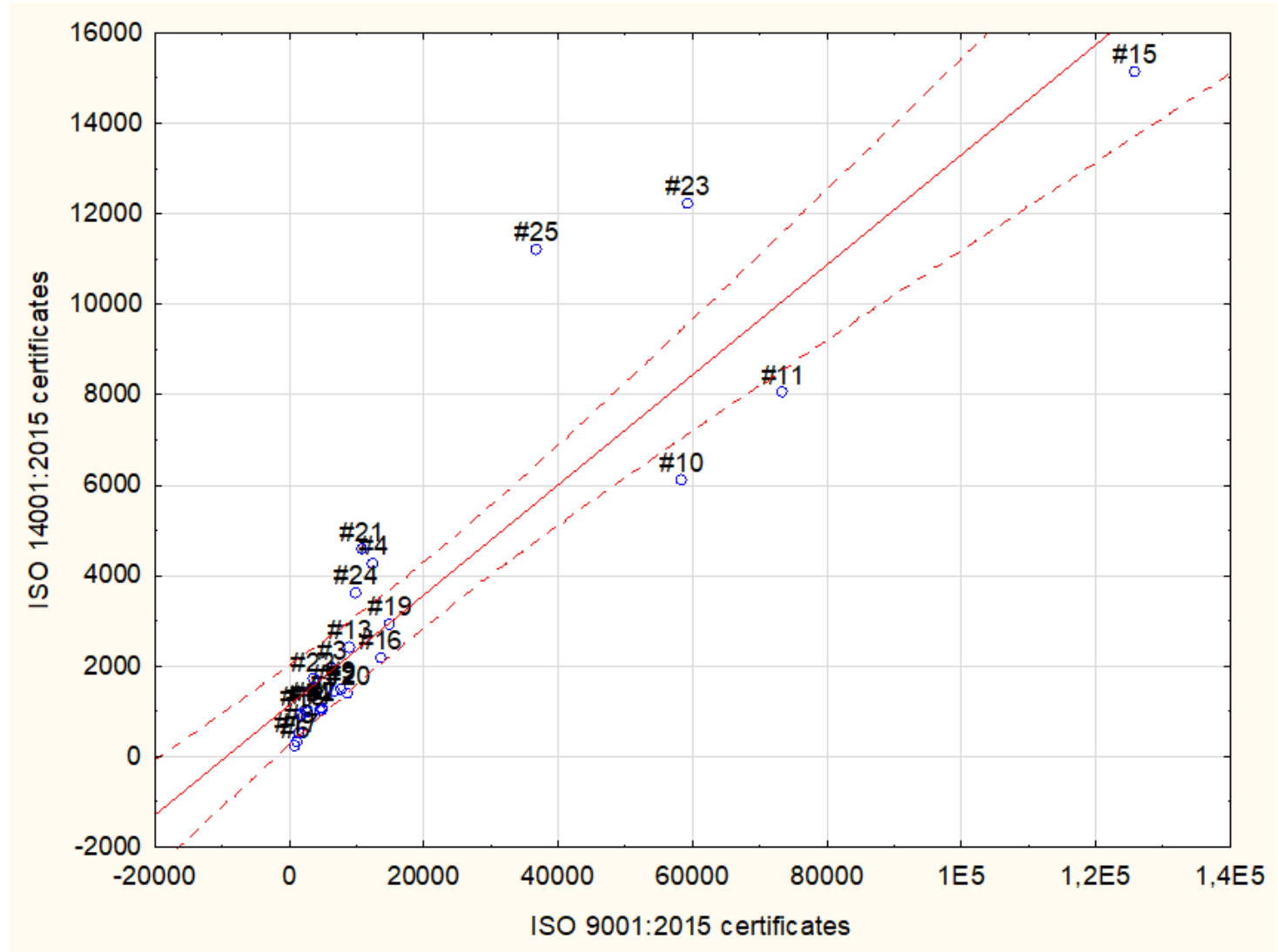

Figure 1. Relationship between the number of ISO 9001:2015 certificates and the number of ISO 14001:2015 certificates in the European Union countries. Author's own work.

Another figure, Figure 2, shows the relationship between the number of ISO 9001:2018 certificates and the number of ISO 45001:2018 certificates for the studied European Union countries. The figures in specific points denote individual countries in accordance with the ordinal number in Table 1. Based on the figure, one can say that for most of the countries there is a direct relation between the number of ISO 9001 certificates and the number of ISO 14001:2018 certificates.

The number of ISO 45001 certificates in a given country can be defined as the following linear function of the number of ISO 9001 certificates.

Number of occupational health and safety management system certificates $=59.58+0.0101 *$ Number of quality management system certificates 


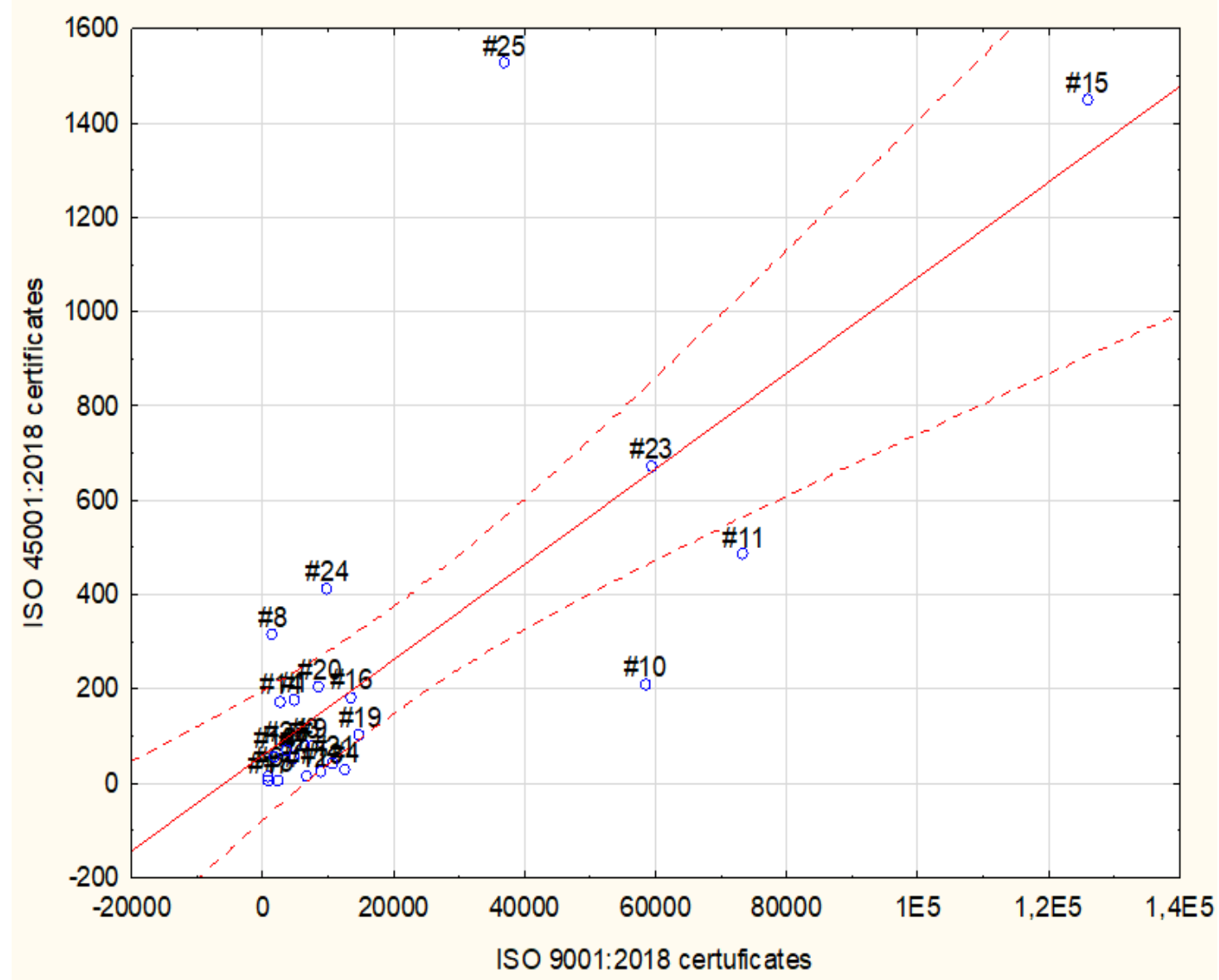

Figure 2. Relationship between the number of ISO 9001:2018 certificates and the number of ISO 45001:2015 certificates in the European Union countries. Author's own work.

In the case of analysis presented in Figure 2, also most of the studied countries, except five of them, are in the confidence interval of 0.95. In three countries (Estonia, Sweden and the United Kingdom) there is an over-representation of implemented occupational health and safety management systems in comparison with quality management systems. This situation is present, in particular, in the United Kingdom, which features the highest number of implemented occupational health and safety management certificates in the European Union, while the number of implemented quality management certificates is moderate. Analyzing historical data, one can observe a decrease in the number of implemented and certified quality management systems and an increase in the number of certified environmental and occupational health and safety management systems in United Kingdom. Many organizations in this country have resigned from implementing a quality management system, unless an integrated system is implemented - then the quality management system is a part of the whole management system of the organization. In this country, which was a pioneer in the implementation of quality management systems, there is a clear shift towards the implementation of industry systems. This is confirmed by the analysis of data concerning the implementation of safety management systems based on the ISO 27001:2015 standard (Table 1). Also in this case, in the United Kingdom there is the highest number of those certificates among all European Union countries. 
Similarly as in the case of analyzing the relation between quality and environmental management systems, also in this case, for the same two countries (France and Germany) there is a slight over-representation of quality management systems in comparison with the number of implemented occupational health and safety management systems. Also here, Italy is a country with very high number of occupational health and safety management systems.

A scatter diagram for the relationship between the number of certificates of the environmental management system and the quality management system is presented in Figure 3. There is a linear correlation at the significance level of $\alpha=0.05$ between analyzed variables. The number of ISO 45001:2015 certificates in a given country can be defined as the following linear function of the number of ISO 14001:2015 certificates.

Number of occupational health and safety management system certificates $=-48.429+0.087$

* Number of environmental management system certificates

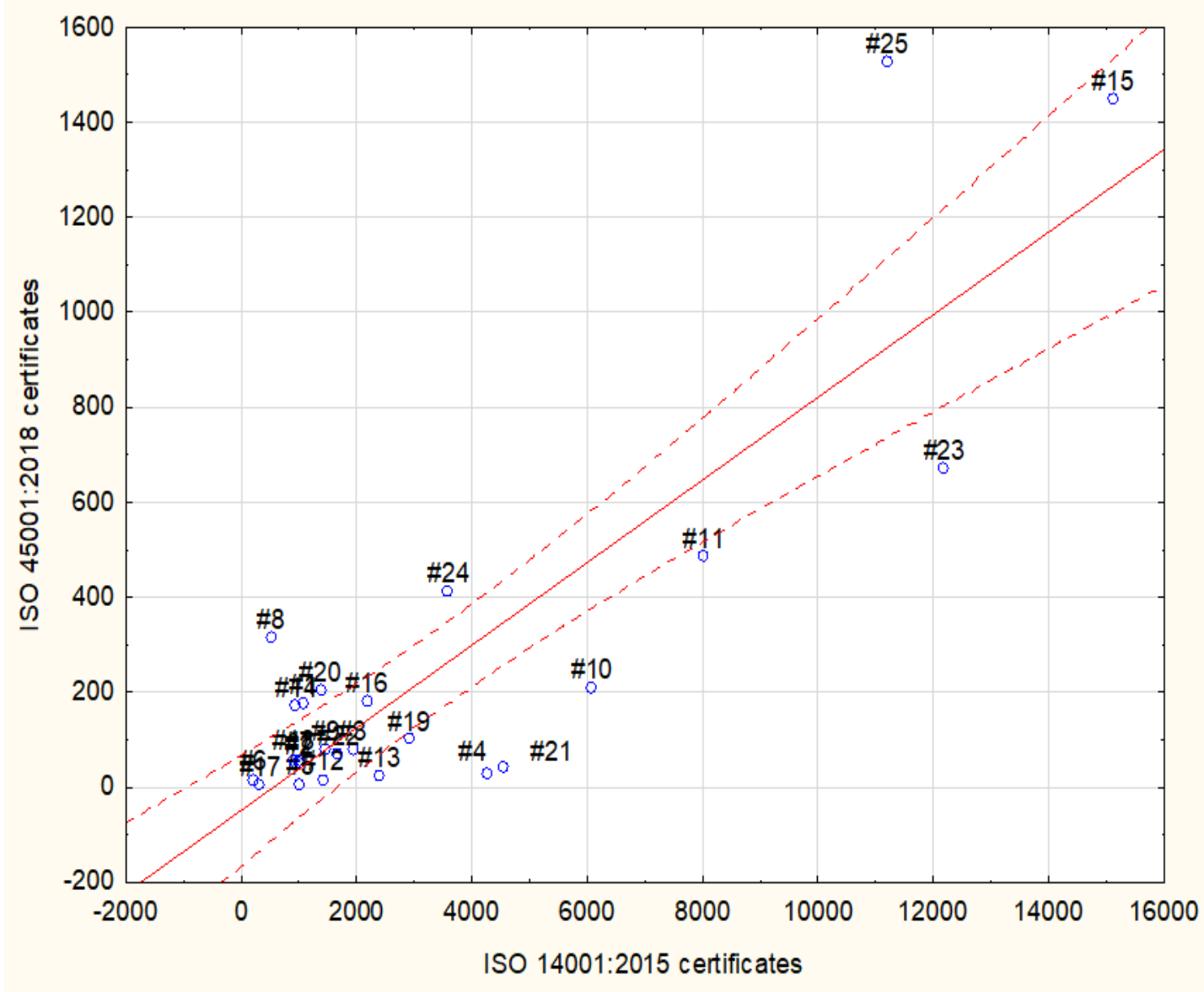

Figure 3. Relationship between the number of ISO 14001:2018 certificates and the number of ISO 45001:2015 certificates in the European Union countries. Author's own work.

The data presented in Figure 3 confirms the previous analyses. In the case of three countries (Estonia, Sweden and the United Kingdom) there is an over-representation of occupational health and safety management systems in comparison with environmental management systems, while this phenomenon is especially strong in the United Kingdom. In five countries (Czech Republic, France, Germany, Romania and Spain) there is an over-representation of 
environmental management systems. In particular, in the case of France and Germany, a traditional pathway to implementing certified management systems can be observed: the predominance of quality systems over environmental ones, which, in turn, predominate over the occupational health and safety management systems.

\section{Conclusion}

The analysis of data concerning the number of ISO 9001:2015, ISO 14001:2015, ISO 27001:2013, ISO 22000:2018 and ISO 45001:2018 certificates implemented in the European Union countries allows to conclude that there are correlations between the number of implemented particular standards. In particular, the presence of a standard concerning the quality management system ISO 9001 is positively correlated with all other analyzed certified management systems. The results of the analysis support the H1 hypothesis, which says: the presence of other industry management systems is positively correlated with the presence of ISO 9001:2015 quality management system in organizations.

The analysis of correlations between particular standards is important to know if the standards are implemented accordingly or separately. The integrated management systems which are implemented nowadays consist of particular standardized systems. Organization to achieve potential to implement integrated system should have some standardized systems implemented accordingly. Information's about correlations between particular system could help government to establish policy to emphasis implementation of those systems which are not widely widespread.

In most European Union countries, implementation of particular standards, especially ISO 9001, ISO 14001 and ISO 45001, is strongly correlated. There are, however, some exceptions. Especially in the United Kingdom, one can observe a shift from ISO 9001 standard towards more and more common implementation of ISO 14001 and ISO 45001 standards, as well as other industry standards. In turn, in France and Germany, certified management systems are, first of all, based on ISO 9001 quality management standards, while implementation of environmental and occupational health and safety management systems takes place with some delay. A different case is Italy, a country which, in absolute values, ranks first in the European Union in terms of certified ISO 9001 and ISO 14001 systems, second in terms of number of ISO 45001 and ISO 22000 certificates, and fourth in terms of ISO 27001 certificates. 


\section{References}

1. Bielawa, A. (2008). System zarządzania bezpieczeństwem informacji według normy ISO/IEC 27001:2005. Studia i Prace Wydziału Nauk Ekonomicznych $i$ Zarzadzania, Uniwersytet Szczeciński, 1, pp. 171-176.

2. Ejdys, J., Kobylińska, U., and Lulewicz-Sas, A. (2012). Zintegrowane systemy zarzadzania jakościa, środowiskiem $i$ bezpieczeństwem pracy. Białystok: Oficyna Wydawnicza Politechniki Białostockiej.

3. Ewertowski, T. (2018). Doskonalenie systemu zgłaszania zdarzeń niepożądanych w organizacjach $\mathrm{w}$ kontekście wdrażania przez nie normy ISO 45001:2018. Zeszyty Naukowe Politechniki Poznańskiej. Organizacja i Zarządzanie, 78, pp. 19-34.

4. Gebczyńska, A., and Wolniak, R. (2018). The impact of quality management systems on the effects of the process approach implementation. Economic Environmental Study, 4, pp. 1235-1259.

5. Górny, A. (2017). Zarządzanie bezpieczeństwem i higiena pracy w doskonaleniu warunków produkcji - implikacyjne aspekty wymagań normy ISO 45001. Problemy jakości, 5, pp. 2-8.

6. Grudowski, P. (2004). Zalecenia dotyczące zarządzania procesowego w systemach jakości małych firm - etap planowania. Problemy Jakości, 3, pp. 25-28.

7. Horodecka, A.M., and Wolniak, R. (2015). Uwarunkowania rynku włoskiego w zakresie implementacji SZJ norm ISO 9000. Problemy Jakości, 12, pp. 22-27.

8. Horodecka, A.M., and Wolniak, R. (2015). Valutazione delle non conformita nell'esempio di un Azienda Italiana, In: J. Kaźmierczak (Eds.), Systemy Wspomagania Inżynierii Produkcji. Review of problems and solutions (pp. 18-31).

9. ISO Survey 2018, https://isotc.iso.org/livelink/livelink?func=1l\&objId=18808772\&obj Action=browse\&viewType=1, 22.09.2019.

10. Krawczuk, A. (2016). Wdrażanie systemu zarządzania jakością wg ISO 9001. Zeszyty Naukowe Uniwersytetu Przyrodniczo-Humanistycznego w Siedlcach. Seria: Administracja i Zarzadzanie, 108, pp. 163-171.

11. Krzyżanowski, L. (1992). Podstawy nauk o organizacji i zarzadzaniu. Warszawa: PWN.

12. Maleszka, A. (2011). Przyczyny i korzyści wdrażania systemu zarządzania bezpieczeństwem informacji w polskich organizacjach posiadających certyfikat ISO/IEC 27001. Zeszyty Naukowe, Uniwersytet Ekonomiczny w Poznaniu, 194, pp. 55-69.

13. Malindžák, D., Pacana, A., and Pačaiová, H. (2017). Effective Model of Environmental and Logistics System Quality Improvements for Cement Factory Vessels. Przemyst Chemiczny, 96(9), pp. 1958-1962. 
14. Olkiewicz, M., and Wolniak, R. (2018). The repationship between the economic development of the country and food security. Rocznik Ochrona Środowiska, 20(10), pp. 804-818.

15. Pacana, A., and Stadnicka, D. (2017). Nowoczesne systemy zarzadzania jakościa zgodne z ISO 9001:2015. Rzeszów: Wydawnictwo Politechniki Rzeszowskiej.

16. Pacana, A., and Ulewicz, R. (2017). Researches of determinants motivating to implementation of the environmental management system. Polish Journal of Management Studies, 16(1), pp. 165-174.

17. Pacana, A., Lew, G., and Kulpa, W. (2017). Rating the quality of implementation of environmental management systems. Journal of Business \& Retail Management Research (JBRMR), 11(2), pp. 165-169.

18. Psomas, E.L., Fotopulos, Ch.V., and Kafetzopulos, D.P. (2011). Motives, difficulties and benefits in implementing the ISO 14001 Environmental Management System. Management of Environmental Quality, 22(4), pp. 502-521.

19. Qi, G., Zeng, S., Yin, H., and Lin, H. (2013). ISO and OHSAS certifications. Management Decision, 51(10), pp. 1983-2005.

20. Searcy, C., Morali, O., and Karapetrovic, S. (2012). An analysis of ISO 14001 and suggested improvements. Journal of Global Responsibility, 3(2), pp. 278-293.

21. Senczyk, D. (2014). Zintegrowane systemy zarządzania w przedsiębiorstwie na wybranych przykładach. Przeglad Naukowo-Metodyczny, 1, pp. 153-161.

22. Senkus, P., and Domańska-Szaruga, B. (2011). System zarządzania bezpieczeństwem informacji według normy ISO 27001 - wdrożenie na świecie. Roczniki Naukowe Stowarzyszenia Ekonomistów Rolnictwa i Agrobiznesu, 2, pp. 423-427.

23. Sułkowski, M., and Wolniak, R. (2018). Poziom wdrożenia instrumentów zarzadzania jakościq w przedsiębiorstwach branży obróbki metali. Częstochowa: Oficyna Wydawnicza Stowarzyszenia Menedżerów Produkcji i Jakości.

24. Turlejska, H. (2010). Zarządzanie bezpieczeństwem żywności - wymagania normy ISO 22000:2006. Żywienie Człowieka i Metabolizm, 37, pp. 2-8.

25. Urbaniak, M. (2006). Systemy zarzadzania w praktyce gospodarczej. Warszawa: Difin.

26. Wolniak, R. (2011). Parametryzacja kryteriów oceny poziomu dojrzałości systemu zarządzania jakością. Gliwice: Wydawnictwo Politechniki Śląskiej.

27. Wolniak, R. (2013). Normalizacja zarządzania jakością a wymiary kulturowe kraju. Problemy Jakości, 9, pp. 19-25.

28. Wolniak, R. (2017). Analiza relacji pomiędzy wskaźnikiem innowacyjności a nasyceniem kraju certyfikatami ISO 9001, ISO 14001 oraz ISO / TS 16949. Kwartalnik Organizacja i Kierowanie, 2, pp. 139-150.

29. Wolniak, R. (2017). Analiza wskaźników nasycenia certyfikatami ISO 9001, ISO 14001 oraz ISO/TS 16949 oraz zależności pomiędzy nimi. Zeszyty Naukowe Politechniki Śląskiej. Seria Organizacji i Zarządzanie, 108, pp. 421-430. 
30. Wolniak, R. (2018). Internacjonalizacja a dojrzałość systemów zarządzania jakościa w przedsiębiorstwach. Gliwice: Wydawnictwo Politechniki Śląskiej.

31. Wolniak, R. (2018). Quality management systems according to ISO 9001:2015 requirements and its improvement. Gliwice: Wydawnictwo Politechniki Śląskiej.

32. Wolniak, R., and Skotnicka-Zasadzień, B. (2014). The use of value stream mapping to introduction of organizational innovation in industry. Metalurgija, 53(4), pp. 709-713.

33. Wolniak, R., and Sułkowski, M. (2015). Motywy wdrażanie certyfikowanych Systemów Zarządzania Jakością. Problemy Jakości, 9, pp. 4-9.

34. Wolniak, R., and Sułkowski, M. (2015). Rozpowszechnienie stosowania Systemów Zarządzania Jakością w Europie na świecie - lata 2010-2012. Problemy Jakości, 5, pp. 29-34.

35. Wolska, E. (2012). Audyt zgodności z normą ISO-IEC 27001-2005. Zeszyty Naukowe Warszawskiej Wyższej Szkoły Informatyki, 7, pp. 79-93.

36. Wysokińska-Senkus, A. (2010). Proces wdrażania i funkcjonowania systemu zarządzania bezpieczeństwem żywności według normy ISO 22000, w zakładzie przetwórstwa mięsnego. Zeszyty Naukowe Uniwersytetu Przyrodniczo-Humanistycznego w Siedlcach. Seria Administracja i Zarzadzanie, 87, pp. 131-141.

37. Zymonik, Z., Hamrol, A., and Grudowski, P. (2013). Zarządzanie jakościa i bezpieczeństwem. Warszawa: PWE. 